\title{
TANTANGAN DAN PELUANG PENGEMBANGAN KETERAMPILAN BAHASA ARAB KOMUNIKATIF DI PESANTREN MODERN GONTOR PUTRI 4 SULAWESI TENGGARA
}

\author{
Imelda Wahyuni \\ (Institut Agama Islam Negeri Kendari)
}

\begin{abstract}
Abstrak:
Ciri khusus pesantren sebagai lembaga Pendidikan Islam adalah terdapatnya pelatihan Bahasa Arab. Dalam hal ini, strategi lembaga pesantren menjadi bahasan penting dalam mendukung pencapaian kemampuan bahasa oleh santri. Tulisan ini mengkaji tentang model pembelajaran bahasa komunikatif yang diterapkan di Pondok Pesantren Modern Darussalam Gontor Putri 4 Sulawesi Tenggara. Data kualitatif deskriptif dikumpulkan melalui wawancara dan observasi. Artikel ini menggali lebih jauh bagaimana pesantren dapat menangkap peluang dan menghadapi tantangan pembelajaran bahasa komunikatif untuk mengembangkan kemampuan bahasa Arab santri. Temuan penelitian ini menunjukkan pengembangan kemampuan bahasa Arab santri terpenuhi dengan adanya tenaga edukasi yang direkrut berdasarkan sistem manajerial terpusat. Sedangkan tantangan pembelajaran bahasa komunikatif dihadapi dengan membangun komitmen santri untuk memperioritaskan upaya berbahasa komunikatif. Peneliti menyimpulkan bahwa dukungan kebijakan pimpinan dalam mengelaborasi tujuan struktural dan fungsional pendidikan bahasa menjadi wilayah dasar dalam perumusan tata kerja program pendidikan di pesantren.
\end{abstract}

Kata Kunci: Pembelajaran Bahasa Komunikatif; Kemampuan Bahasa Arab; Pondok Pesantren. 


\begin{abstract}
:
What specializes pesantren as an Islamic educational institution is the existence of Arabic language training. In this discourse, pesantren institutional strategy goes important in sustaining santri's language learning achievement. This paper examines communicative language learning model at Pondok Pesantren Modern Darussalam Gontor Putri 4 of Sulawesi Tenggara. Qualitative-descriptive data were collected through interview and observation. This article explores how pesantren deals with challenge and opportunity to communicative language learning in order to develop santri's Arabic language ability. Findings show positive language learning achievement because of the availability of educators which are recruited by central management. Various challenges in the learning are managed by developing santri's commitment to prioritize communicative language efforts. In conclusion, leader's policy support in elaborating structural and functional of language learning becomes fundamental domain in formulating education program mechanism in pesantren.
\end{abstract}

Keywords: Communicative Language Learning; Arabic Language Skill; Pondok Pesantren.

\title{
A. Pendahuluan
}

Pembelajaran bahasa asing di Indonesia telah berlangsung sejak zaman kolonial. Pembelajaran bahasa Inggris dilaksanakandi sekolah-sekolah tertentu dan diperuntukkan bagi anak-anak bangsawan Belanda dan menjadi symbol "kelas sosial" yang tinggi. Sedangkan pembelajaran bahasa Arab berlangsung di kalangan masyarakat agamis. Kedua bahasa Asing tersebut mewarnai dinamika pembelajaran dalam dunia pendidikan di Indonesia mulai pada jenjang pra sekolah sampai pada jenjang pendidikan tinggi. Tujuan pembelajaran tersebut adalah untuk memenuhi kebutuhan praktis sebagai representasi dari kearifan lokal pada setiap daerah untuk menghadapi tantangan dunia globalisasi. Kedua bahasa Asing ini sangat berkontribusi terhadap pemenuhan kebutuhan ilmu alat bagi setiap pembelajar. Secara khusus, bahasa Arab menjadi ilmu alat sekaligus sebagai media komunikasi dalam kajian pendidikan Islam.

Pesantren hadir di tengah popularitas lembaga pendidikan yang dikenal dengan sebutan "madrasah".1 Pesantren terkenal sebagai lembaga pendidikan Islam yang berakar dan tumbuh berkembang melalui asimilasi budaya di Indoneisa. ${ }^{2}$ Pondok pesantren menjadi salah satu wadah representatif membudayakan pembelajaran bahasa Arab dan bahasa Inggris sebagai upaya pengembangan kemampuan dan penguasaan kedua bahasa Asing tersebut. Corak

\footnotetext{
${ }^{1}$ Ismail Baharudin, "Pesantren dan Bahasa Arab," Jurnal Thariqoh Islamiah 1, no. 1, (Januari 2014): 17.

2 Ismail Suardi Wekke\& Andriansyah, "From Gontor to Sorong: Muslim Minority Practices on Arabic Teaching and Learning," SOSIOHUMANIKA: Jurnal Pendidikan Sains Sosial dan Kemanusiaan 9, no. 1 (Mei 2016): 49.
} 
pembelajaran bahasa Arab dan bahasa Inggris mengikuti kecenderungan sistem pembelajaran pondok pesantren, pembelajaran melalui pembiasaan komunikasi berbahasa Arab dan Inggris. Lingkunan pesantren mendukung penerapan pembelajaran kondusif dan adaptif terhadap kebutuhan pengembangan bahasa Arab dan bahasa Inggris para santri. Kemandirian berbahasa para santri terbentuk sejak awal dan dapat memperkaya pengalaman berkomunikasi, baik pengalaman menyampaikan ide maupun pengalaman menangkap pendapat orang lain.

Penelitian sebelumnya mengkaji tentang pesantren tetapi fokus pada kemandirian ekonomi pesantren. ${ }^{3}$ Isbah juga telah melakukan pengkajian tentang pesantren tetapi fokus pada faktor-faktor yang mempengaruhi keterlibatan pesantren dalam urusan sosial ekonomi untuk kesejahteraan masyarakat. ${ }^{4}$ Sedangkan kajian ini fokus terhadap pembelajaran bahasa Arab. Model pembelajaran bahasa Arab pada pondok pesantren tertentu terkesan masih sangat tradisional dan hanya sekedar memenuhi persyaratan umum sebuah pembelajaran berbasis pondok pesantren. Kurikulum pesantren menunjukkan bahwa setiap tingkatan diharuskan belajar bahasa Arab dan didistribusikan pada masa awal studi santri, hal ini dimaksudkan untuk menjadikan santri mampu memahami bahasa Arab sebagai ilmu alat dalam mengembangkan pengetahuan. Pembelajaran bahasa Arab pada pondok pesantren sangat dipengaruhi oleh model pembelajaran pada jenjang sekolah. Pada jenjang sekolah dasar, target yang dikejar adalah bagaimana siswa dapat lulus dalam ujian akhir, khususnya pada mata pelajaran Agama yang di dalamnya terdapat materi bahasa Arab. Pembelajaran bahasa Arab mendapat perhatian, namun perhatian tersebut terkooptasi pada kebutuhan jangka pendek, yaitu peserta didik mengejar target kelulusan berbasis perolehan nilai tetapi target yang terkait dengan kebutuhan komunikasi belum menjadi target secara maksimal.

Kenyataan ini mengalami perubahan secara perlahan, seiring dengan meningkatnya jumlah pondok pesantren modern yang tersebar di beberapa wilayah Indonesia. Pesantren menekankan pentingnya penguasaan bahasa Arab, sehingga tujuan pembelajaran bahasa Arab sangat bervariasi. Lembaga pendidikan berbasis pesantren ini menekankan tujuan pembelajaran bahasa secara fungsional, sehingga pihak lembaga menyediakan pelayanan peningkatan pendidikan Islam terkait pembelajaran bahasa. Hal ini dimaksudkan untuk memenuhi ketercapaian tujuan pembelajaran bahasa Arab. Tujuan struktural pembelajaran bahasa Arab disempurnakan dengan memaksimalkan tujuan

3 Mohammad Muchlis Solichin, "Kemandirian Pesantren di Era Reformasi," Nuansa 9, no. 1 (Januari - Juni 2012): 190.

4 M. Falikul Isbah, Pesantren dan Aktivitas Sosial-Ekonomi yang Mengakar di Masyarakat, (Jakarta: PPIM UIN Jakarta, 2017), 408. 
fungsional. Upaya tersebut belum sepenuhnya dapat tercapai, namun dampak positif yang terlihat sebagai realitas pergeseran tujuan pembelajaran bahasa Arab mempengaruhi eksistensi pesantren modern di kalangan masyarakat Indonesia.

Makruf telah meneliti tentang pembelajaran bahasa Arab namun fokus pada sistem pembajaran bahasa Arab yang mengintegrasikan proses pembelajaran madrasah dengan pondok pesantren. ${ }^{5}$ Proses integrasi yang diteliti terkait sistem pembejaran pesantren yang diadopasi pada pembelajaran madrasah. Sedangkan penelitian ini lebih interes pada kajian penerapan pembelajaran bahasa komunikatif. Model pembelajaran bahasa Arab, khususnya pada pesantren modern telah mengalami pergeseran dari pembelajaran berbasis metode tradisional menjadi pembelajaran yang relevan dengan bentuk edukasi berbasis pendidikan modern. Pada awal masa perkembangan pesantren, pembelajaran bahasa Arab lebih dominan menggunakan pendekatan dan model tradisional yang bentuk keterampilan berbahasanya hanya satu arah. Oleh karena itu, fenomena pergeseran ini menuai perdebatan di kalangan ahli atau pakar, sehingga menjadi alasan pentingnya penelitian ini dilakukan.

Salah satu model tersebut adalah pembelajaran bahasa komunikatif, yaitu pembelajaran yang menekankan tujuan fungsional. Namun realitas yang terjadi, pergeseran penerapan model tersebut menciptakan peluang dan tantangan bagi terwujudnya pembelajaran bahasa komunikatif. Pemilihan sebuah pendekatan yang relevan dengan pembelajaran bahasa komunikatif salah satunya adalah pendekatan komunikatif. Penggunaan pendekatan ini tetap terintegrasi dengan kondisi obyektif lingkungan belajar, khususnya pada lingkungan pesantren. Terkait lingkungan, Reuter sebagai peneliti di Asia Institut dalam penelitiannya menyebutkan bahwa ada dua hal yang menggembirakan dari gerakan "go green" di Indonesia, yaitu: pertama, anstusiasme pemikiran keislaman di kalangan organisasi Islam; kedua, pesantren dalam menggali nilai-nilai Islam terkait ekologi. ${ }^{6}$ Secara khusus titik singgung kajian Reuter dengan penelitian ini ada pada fungsi pesantren dalam mengakomodir nilai-nilai lingkungan berkomunikasi.

Kajian ini mengambil kasus pada Pondok Pesantren Modern Darussalam Gontor Putri 4 Sulawesi Tenggara. Santriwati berasal dari berbagai daerah dan beragam suku, sehingga terjadi asimilasi budaya dan bahasa. Pengumpulan data penelitian kualitatif deskriptif ini menggunakan teknik observasi terhadap pembelajaran bahasa Arab dan wawancara kepada ustadz dan ustadzah untuk memperoleh data penelitian terkait tantangan dan peluang pengembangan

5 Imam Makruf, "Manajemen Integrasi Pembelajaran Bahasa Arab di Madrasah Berbasis Pondok Pesantren," Cendekia 14, no. 2 (Juli - Desember 2016): 269.

6 Thomas A. Reuter, "The Green Revolution in the Word's Religions: Indonesian Examples in Internasional Comparison," Religions 6, (Maret 2017): 1217-1231. 
kemampuan bahasa Arabdi Pesantren Modern Gontor Darussalam Putri 4 Sulawesi Tenggara, tepatnya di Desa Lamomea. Hasil penelitian ini diharapkan dapat berkontribusi terhadap akselerasi progres pondok pesantren secara massif dapat mengembangkan keterampilan bahasa Arab melalui model pembelajaran bahasa komunikatif. Harapan ini sekaligus untuk menegaskan urgensi pembelajaran bahasa komunikatif pada seluruh tingkatan melalui identifikasi kemampuan dasar santriwati.

\section{B. Pembelajaran Bahasa Arab di Pondok Pesantren di Indonesia}

Pembelajaran Bahasa Arab di Indonesia telah diajarkan sejak masa pra sekolah, jenjang pendidikan dasar dan menengah hingga ke perguruan tinggi. ${ }^{7}$ Secara khusus, pembelajaran bahasa komunikatif di lembaga pendidikan pesantren menunjukkan adanya usaha untuk meningkatkan mutu lembaga dan memajukan sistem pendidikan. Pesantren dengan corak khusus menggabungkan dua kurikulum dalam sistem pendidikan, yaitu kurikulum pendidikan umum dan kurikulum pendidikan agama. Ciri khas ini menjadi tanda menarik karena output pembelajaran dapat dicapai berdasarkan tujuan pendidikan yang tertuang pada kedua kurikulum tersebut. Setidaknya terdapat beberapa orientasi pendidikan yang dapat dijelaskan pada bagian ini, yaitu orientasi akademik dan orientasi pragmatik.

Orientasi akademik belajar bahasa Arab adalah bertujuan untuk memahami ilmu pengetahuan yang terkandung dalam referensi berbahasa Arab, tingkat pemahaman sangat tergantung pada keterampilan Bahasa Arab, yaitu keterampilan berbicara, membaca, menyimak, dan mendengar. Orientasi ini lebih memposisikan Bahasa Arab sebagai ilmu yang harus dikuasai secara akademik, sehingga secara teknis dapat berguna untuk memandu kemampuan memahami literatur yang berbahasa Arab. Salah satu bentuk usaha yang relevan dengan orientasi akademik adalah telah diadakan jurusan yang secara khusus tentang pembelajaran Bahasa pada jenjang Sekolah Menengah Tingkat Atas (SMTA), yaitu Madrasah Aliyah (MA) atau Sekolah Menengah Atas (SMA) di Indonesia. Orientasi akademik lainnya adalah santriwati pesantren Gontor Putri 4 lebih terampil dalam menyelesaikan tugas-tugas akademik yang diberikan oleh tenaga pendidikan, sehingga dapat menunjukkan prestasi berbasis keterampilan berbahasa Arab.

Selanjutnya secara khusus pada jenjang pendidikan tinggi, terdapat program studi Pendidikan Bahasa Arab, dan program studi Bahasa dan Sastra Arab, baik pada Perguruan tinggi Islam maupun pada Perguruan tinggi Umum. Adapun orientasi professional atau orientasi pragmatik, yaitu belajar bahasa untuk profesi. Misalnya mampu berkomunikasi menggunakan bahasa Arab atau

7 Ismail Suardi Wekke, "Arabic Language Teaching and Learning in Muslim Minority of West Papua," Jurnal Pendidikan Islam 6, no. 1, (June 2017): 156. 
Imelda Wahyuni

Bahasa Inggris dapat membantu mahasiswa dalam melanjutkan studi di negara Barat atau negara Timur Tengah. Kedua orientasi ini menjadi tujuan pembelajaran bagi seluruh santri pesantren di Indonesia.

Pesantren mengalami pertumbuhan pesat di persada Indonesia, secara kuantitas menunjukkan peningkatan dari tahun ke tahun. Berdasarkan data dari Kementerian Agama disebutkan bahwa jumlah pesantren di Indonesia pada tahun 1997 mencapai jumlah 9388 pesantren, selang hampir dua dekade pada tahun 2016 tercatat pada data Sistem Informasi, dan Hubungan Masyarakat Sekretariat Direktorat Jenderal Pendidikan Islam Kementerian Agama, jumlahnya mencapai 28,194 pesantren yang ada baik di wilayah kota maupun pedesaan dengan jumlah santri 4,290,626.8 Jumlah tersebut sangat fantastik dan dapat memberi dukungan kelembagaan, khususnya pendidikan berbasis pesantren. Eksistensi pesantren di berbagai wilayah membuktikan bahwa karakter pendidikan pesantren memiliki kans di benak masyarakat sehingga mereka memilih pesantren sebagai wadah pembelajaran.

Pembelajaran bahasa Arab tidak hanya diajarkan pada beberapa pesantren tradisional akan tetapi diajarkan pada pesantren modern, bahkan pada lembaga pendidikan selain pesantren, baik dalam negeri maupun di luar negeri. ${ }^{9}$ Secara khusus, di berbagai negara pembelajaran bahasa Arab bertujuan untuk membekali pengetahuan dasar bahasa Arab bagi peserta didik. ${ }^{10}$ Mata pelajaran bahasa Arab yang didistribusikan pada semua jenjang berdasarkan kurikulum yang berlaku. Penelitian yang dilakukan Wekke menemukan bahwa dalam penetapan sebuah kurikulum merujuk padatahapan tertentu. Disebutkan bahwa salah satu model pengembangan kurikulum yang representatif adalah Iterative Curriculum Discourse Analysis (ICDA) yang memiliki tujuh langkah praktis dalam melakukan analisis struktural. Salah satunya adalah mengelaborasi tiga komponen penting, yaitu: keagamaan, identitas, dan nilai pada masyarakat. ${ }^{11}$ Berbeda dengan penelitian tersebut, kajian ini fokus pada pembelajaran bahasa memiliki persamaan pembelajaran bidang keilmuan lainnya, terdiri dari komponen penting dalam pembelajaran, seperti kesesuaian antara metode, materi, strategi, dan media pembelajaran. Komponen tersebut harus bersinergi antara satu komponen dengan komponen lainnya, selain itu

8 Muhyiddin, "Pertumbuhan Peasantren di Indonesia Dinilai Menakjubkan," Republika.co.id, 30 November 2017, diakses 17 Februari 2017 https://www.republika.co.id/berita/duniaislam/islam-nusantara/17/11/30/p088lk396-pertumbuhan-pesantren-di-indonesia-

dinilai-menakjubkan.

9 Wekke, “Arabic Language,” 147.

${ }^{10}$ A. C. Mat, "Situasi Pembelajaran Bahasa Asing di Institut Pengajian Tinggi: Perbandingan antara Bahasa Arab, Bahasa Mandarin dan Bahasa Perancis," Asean Journal of Teaching and Learning in Higher Education (AJTLHE) 2, (Februari 2010), 9.

${ }^{11}$ Ismail Suardi Wekke, "Tradisi Pesantren dalam Konstruksi Kurikulum Bahasa Arab di Lembaga Pendidikan Minoritas Muslim Papua Barat, KARSA 22, no. 1, (Juni 2014): 22. 
setiap komponen harus terencana dan tertuang dalam perencanaaan pembelajaran. ${ }^{12}$

Pesantren Modern Darussalam Gontor (PMDG) tersebar di beberapa kawasan Indonesia sejak tahun 1926 hingga saat ini, popularitas pondok gontor dikenal oleh masyarakat sebagai wadah belajar yang berbeda dengan lembaga lainnya. (kebanyakan di daerah Jawa). Menghampiri 100 tahun berkiprah di kancah pendidikan, pondok pesantren Gontor semakin memperkokoh eksistensinya dengan mengembangkan daya tarik yang dimilikinya. Pada mulanya hanya didirikan untuk kategori putra, namun selang beberapa tahun kemudian kategori putri juga didirikan untuk memenuhi permintaan masyarakat, baik yang berada di sekitar lingkungan pesantren maupun yang berada di luar kota lokasi pesantren. Secara khusus, pondok putri tersebar di empat kota dan salah satunya adalah Gontor Putri 4 yang berada di Desa Lamomea, Kecamatan Konda, Kabupaten Konawe Selatan, Provinsi Sulawesi Tenggara yang didirikan sekitar bulan Maret 2004 dan dapat menerima pendaftran santriwati baru pada tahun ajaran 2004/2005. Pesantren Gontor Putri 4 menggunakan sistem boarding school, dimana seluruh santri diharuskan tinggal di pondok sesuai kategori programnya, yaitu program reguler selama 6 (enam) tahun dan program intensif selama 4 (empat) tahun. Kedua program ini terdapat pada jenjang pendidikan tingkat menengah, yang populer dengan istilah Kulliyyatu al-Muallimin al-Islamiyah. ${ }^{13}$ Kondisi ini memberi kesempatan pada setiap santri untuk memperdalam ilmu pengetahuan, termasuk pembelajaran bahasa Arab. Kegiatan akademik berbasis (KMI) juga memprogramkan kegiatan ekstra kurikuler yang dapat memediasi keterampilan berbahasa santriwati, seperti lomba pidato bahasa Asing (Arab-Inggris), debat bahasa (Arab dan Inggris), kegiatan pramuka, kegiatan seni dan kegiatan lainnya.

Tenaga pendidik Pondok Pesantren Modern Darussalam Gontor Putri direkrut berdasarkan sistem pengelolaan terpusat. Para Alumni dapat langsung mengabdikan diri sebagai ustadz dan ustadzah dengan beberapa ketentuan yang diatur secara internal dan dipedomani dalam mengembangkan pondok pesantren, baik secara kuantitas maupun secara kualitas. Secara kuantitas, terdapat 21 dari 70 tenaga pengajar yang berasal dari Kendari dan 59 lainnya berasal dari provinsi lain di belahan Indonesia. Fakta ini menggambaran bahwa asimilasi budaya terjadi pada setiap komponen yang terlibat pada lembaga pendidikan Islam tersebut. Sedangkan secara kualitas, kemampuan mengajar para ustadz ustadzah didukung dengan kualifikasi pendidikan. Data yang ditemukan menunjukkan bahwa sekitar 20\% tenaga pendidik gontor Putri 4

\footnotetext{
12Muh. Ariadi Muslim, "Manajemen Pembelajaran Bahasa Arab di Pondok Pesantren Nurul Hakim (Putra) Kediri NTB" (Tesis, UIN Sunan Kalijaga, 2016), vii.

13Wekke dan Andriansyah, "From Gontor to Sorong," 50.
} 
Imelda Wahyuni

sedang melanjutkan kuliah, baik pada jenjang strata satu maupun pada jenjang magister.

Penuturan beberapa informan menyebutkan bahwa mereka melanjutkan studi dengan izin unsur pimpinan, praktis realita ini menggambarkan bahwa upaya peningkatan keterampilan tidak hanya diupayakan bagi santriwati tetapi juga diprioritaskan bagi tenaga pendidiknya. Pengembangan wawasan sangat tegas dilakukan karena seluruh tenaga pendidik yang sedang kuliah pada jenjang Strata Satu (S1) tersebut memilih jurusan pendidikan Bahasa Arab. Konstruk ilmu pengetahuan yang dimiliki oleh setiap tenaga didik tersebut tercermin melalui aktivitas pembelajaran yang dilakukan pada kelas pembelajaran bahasa Arab yang diamanahkan kepada mereka.

Materi pembelajaran bahasa Arab pada Pondok Gontor Putri dibedakan berdasarkan program reguler dan program intensif, namun tetap mengacu pada asas kebutuhan belajar santriwati. Pelaksanaan pembelajaran bahasa Arab berlangsung dengan penyampaian materi yang bervariasi sesuai dengan sistematika yang berlaku pada kurikulum pesantren dan kurikulum umum. Mata Pelajaran berdasarkan kurikulum agama atau pesantren masih mencantumkan materi yang bermuara pada pencapaian empat keterampilan, yaitu keterampilan reseptif terdiri dari keterampilan menyimak dan membaca. Sedangkan keterampilan produktif terdiri dari keterampilan menulis dan berbicara.

\section{Kompetensi Komunikatif dalam Pembelajaran Bahasa Arab}

Penggunaan makna communicative competence terbilang tidak asing karena istilah ini telah banyak digunakan, baik oleh tenaga pendidik selaku pengajar bahasa maupun para penulis yang menggunakan istilah tersebut dalam teks buku ajar bahasa. Pemakaian istilah ini sangat beragam, terdapat beberapa individu yang telah menggunakannya dengan makna yang pasti dan tepat, namun masih terdapat pula yang sebatas pemaknaan terbatasatau disebabkan oleh suatu hal yang melatarbelakanginya, dan kategori ketiga terdapat pula santriwati yang masih kurang maksimal dalam memaknainya. ${ }^{14}$ Pada hakikatnya, terdapat beberapa ustadzah yang menggambarkan pemaknaan istilah tersebut secara abstrak, pemahamannya terwakili oleh kemampuan mereka untuk menyatakan pendapat menggunakan bahasa yang sedang diajarkan.

Kompetensi komunikatif di kalangan tenaga pendidik pesantren dipahami dengan jelas sebagai bagian penting dalam belajar sebuah bahasa. Kompetensi komunikatif dapat dikaitkan dengan kecenderungan santriwati dalam menunjukkan kemampuan berinteraksi dengan yang lainnya, baik kepada para ustadz dan ustadzah maupun kepada sesama santriawati. Seorang santri mengeksplorasi penguasaan kosa kata dengan memaksimalkan kemampuan

${ }^{14}$ Sandra J. Savignon, Communicative Competence: Theory and Classroom Practice,(Massachusetts: Addison Wesley Publishing Company, 1983), 123. 
struktural untuk merangkai kata kata tersebut sehingga dapat digunakan dalam bahasa Arab. Kondisi obyektif santriwati tersebut senada dengan pendapat beberapa ahli/pakar linguistik berdasarkan sudut pandang mereka masingmasing tentang kompetensi komunikatif. ${ }^{15}$ Menurut hasil penelitian Wei kompetensi komunkatif dapat dipahami sebagai pengetahuan dan kemampuan untuk menunjukkan perilaku komunikatif yang tepat dalam konteks interaksi. ${ }^{16}$

Kemahiran mengungkapkan suatu ide dalam bentuk kalimat sederhana menjadi strategi awal bagi pemula, meskipun dalam praktiknya masih terdengar beberapa kata yang pengucapannya terbata-bata atau seakan-akan tersandung perasaan ragu. Hal ini dikonfirmasi kepada salah satu santriwati yang ikut merasakan proses transfer bahasa lokal dengan bahasa Asing sehingga mereka mengakui masih terbatasi oleh aturan gramatikal dalam meyakinkan ketepatan susuan kalimat yang sedang diproduksinya. Fakta ini dapat dikaitkan dengan pendapat Chomsky bahwa istilah kompetensi yang dipahami terbatas pada sistem linguistik atau pengetahuan kaidah bahasa secara hampa. ${ }^{17}$ Kompetensi merupakan pemahaman terhadap peraturan dan tanda tata Bahasa, pemahaman tersebut direfkelsikan dengan praktik kemampuan menghasilkan kalimat yang sistematis berdasarkan kaidah bahasa secara tepat dan benar, hal ini menunjukkan kompetensi linguistik. ${ }^{18}$ Kompetensi linguistik teridentifikasi melalui kemampuan abstraksi perbendaharaan kosa kata untuk memproduksi kalimat yang mudah diserap oleh lawan bicara untuk menyampaikan ide tertentu.

Dell Hymes, pada beberapa literatur mendeskripsikan pendapatnya terkait "kemampuan komunikatif", secara khusus yang tertuang pada artikel berjudul "On Communication Competence" dalam teks yang berbunyi "Theory of communicative competence was a definition of what a speaker needs to know in order to be communicatively competent in a speech community." Teks bahasa Asing ini mengandung makna bahwa kemampuan komunikatif adalah penguasaan alami yang ditunjukkan oleh pembicara dengan menggunakan dan memahami bahasa secara proporsional dalam proses berkomunikasi atau berinteraksi dengan lawan bicara. Santriwati dan tenaga pengajar pada Pokdok

\footnotetext{
${ }^{15}$ Margie Berns, Context of Competence: Socio and Cultural Considerations in Communicative Language Teaching, (New York: Plenum Press, 1990), 165-166. Bandingkan dengan Jack C. Richards dan Theodore S. Rodgers, Approaches and Methods in Language Teaching, (New York: Cambridge University Press, 2001), 69. D. H. Hymes, On Communicative Competence dalam C. Brumfit and K. Johnson (eds.), The Communicative Approach to Language Teaching, (Oxford: Oxford University Press, 1979), 142.

${ }^{16} \mathrm{Hu}$ Wei, "Communicative Language Teaching in the Chinese Environment," US-China Education Review 7, no.6, (June 2010): 104.

${ }^{17}$ Noam Chomsky, Aspect of Theory of Syntax, (Massachusetts: MIT Press, 1965), 112.

${ }^{18}$ J. Munby, Communicative Syllabus Design (Cambridge: Cambridge University Press, 1978), 22.
} 
Pesantren Gontor Putri bertutur alami menggunakan bahasa Arab dan tidak memperioritaskan ketepatan struktural terlebih dahulu karena tenaga pengajar memberi kesempatan yang luas kepada setiap santriwati untuk mengekspresikan keterampilan berbicara dahulu, setelah pembincangan selesai dengan sempurna maka tenaga pengajar memberi saran struktural berbasis uraian gramatikal atau ilmu nahwu dan shorof.

Selanjutnya Hymes mengklaim pendapatnya adalah perpanjangan makna dari konsep yang dipopulerkan oleh Chomsky. Argumen Chomsky terkait kompetensi komunikatif disandarkan pada dua hal terkait dengan bahasa dan linguistik. Pertama adalah pembatasan domain penemuan linguistik terhadap kompetensi gramatikal, yaitu pengetahuan tentang aturan tata bahasa. Bagi Hymes, tugas linguis tidak hanya mendeskripsikan yang diketahui pembicara tentang tata bahasa tetapi juga mempertimbangkan fakta bahwa "anak normal memperoleh pengetahuan tentang kalimat tidak hanya sebagai gramatikal tetapi juga kesesuaian."19

Berbeda dengan gagasan tersebut Richards melihat kompetensi komunikatif sebagai pemahaman "bagaimana menggunakan bahasa untuk berbagai tujuan dan fungsi yang berbeda," memahami bagaimana untuk menyesuaikan bahasa tergantung pada pengaturan (sosio-linguistik), "mengetahui bagaimana untuk menghasilkan dan memahami berbagai jenis teks" seperti wawancara dan percakapan misalnya, serta memiliki kemampuan untuk melanjutkan komunikasi meskipun keterbatasan seseorang dalam bahasa melalui penggunaan strategi yang berbeda. ${ }^{20}$ Hasil pengamatan peneliti menemukan bahwa setiap kemampuan linguistik santriwati dibangun berdasarkan modal berbicara, yaitu ketersediaan kosa kata. Terlihat sangat jelas bahwa santriwati tersebut memiliki tingkat kecermatan berpikir dan mampu mengumpulkan kekuatan untuk mengungkapkan kata demi kata yang telah diramu dalam benaknya. Hal ini menandakan bahwa keterampilan berbicara harus didukung dengan hal lain di luar keterampilan itu sendiri, yaitu kosa kata memadai. Kalimat atai ide tidak dapat disampaikan dengan cermat, ketika santriwati mendapat tekanan psikis terkait rasa malu karena tidak mengetahui bahasa Arab dari kosa kata yang dibutuhkannya. Inilah yang disebut oleh ahli sebagai kompetensi linguistik.

Sedangkan kompetensi komunikatif santriwati teramati melalui kemampuan menirukan bunyi dari setiap kata pilihan untuk menyampaikan ide dan pendapatnya. Beberapa analisis terkait kompetensi komunikatif ditemukan

${ }^{19}$ Dell Hymes, "Competence and Perfomance in Linguistic Theory" dalam R. Huxley \& E. Ingram (Eds.), Language acquisition: Models and methods, (London: Academic Press, 1971), 178.

${ }^{20}$ J. C. Richards, Communicative Language Teaching Today, (Cambridge: Cambridge University Press, 2006), 9. 
dari linguis yang lain. Canale dan Swain mengakumulasi berbagai titik pandang kompetensi komunikatif menjadi koheren, orientasi linguistik, dan kerangka pedagogis yang bermanfaat, dengan alasan bahwa kompetensi komunikatif minimal mencakup empat bidang pengetahuan dan keterampilan. Usaha membangun penggunaan bahasa secara struktural dan pragmatik menginginkan sasaran pembelajaran bahasa yang komunikatif, yaitu meliputi empat kompetensi: kompetensi gramatikal, sosiolinguistik, wacana, dan strategis. Setiap kompetensi ini saling medukung dalam sinergitas yang bersenyawa dan saling membutuhkan satu sama lain. Santriwati yang memiliki keperibadian pendiam terlihat lemah pada kompetensi sosiolinguistik.

Berbanding terbalik dengan kenyataan yang dihadapi pada kebanyakan kelas pembelajaran bahasa Arab di Indonesia, tidak terkecuali pada pembelajaran bahasa Arab di pesantren Gontor Putri 4, bahasa Arab sebagai bahasa asing bagi santri. Santri pada pondok tersebut bukan pengguna bahasa ajar (non-native speaker) dan berada pada lingkungan berbahasa yang tidak kondusif. Pengelola pesantren telah mendesain suasana lingkungansecara maksimal untuk membudayakan bahasa ajar dengan memperdengarkan bahasa tersebut dalam kelas, namun tidak jarang usaha ini mengalami hambatan karena proses penyimakan tidak ditopang dengan perbendaharaan kosa kata yang memadai. Kondisi ini membutuhkan waktu yang relatif banyak untuk menjelaskan kembali makna setiap kalimat dalam bahasa pertama pada umumnya, yaitu bahasa Indonesia. Azhar Arsyad berpendapat bahwa peserta didik memerlukan sesegera mungkin kebiasaan mendengarkan bunyi yang belum dikenal atau belum pernah didengarkan. Gunakanlah bahasa ajar dalam memberikan instruksi kepada peserta didik untuk melakukan sesuatu dalam kelas pada kondisi alami berdasarkan realitas. ${ }^{21}$

Pandangan kalangan komunikatif menyatakan bahwa pembelajaran bahasa bermula dari suatu teori yang berlandaskan bahasa sebagai media komunikasi. Terkait dengan hal tersebut Hymes ${ }^{22}$ menyatakan bahwa tujuan pembelajaran bahasa adalah mengembangkan kompetensi komunikatif. Sedangkan Littlewood, mendeskripsikan dua karakteristik pembelajaran bahasa berdasarkan pendekatan komunikatif, yaitu: pertama, materi pembelajaran bahasa terdiri dari fungsi-fungsi bahasa di samping struktur bahasa. Kedua, peserta didik diberi kesempatan baik secara kelompok maupun individual untuk menggunakan berbagai sumber untuk menyelesaikan masalah, karena manusia merupakan makhluk individu sekaligus merupakan makhluk sosial.

\footnotetext{
${ }^{21}$ Azhar Arsyad, "Mengefektifkan Pendidikan Bahasa Asing di Universitas" dalam Azhar Arsyad, Membangun Universitas Menuju Peradaban Islam Modern, Cet. I, (Makassar: Alauddin Press, 2009), 86.

${ }^{22}$ Hymes, “On Communicative Competence," 27.
} 
Imelda Wahyuni

Salah satu solusi tersebut adalah penggunaan pendekatan berbasis kompetensi dan teknologi informasi yang mempelihatkan kemajuan pada formasi kompetensi komunikatif para ahli di masa yang mendatang. Korelasi antara pendekatan berbasis kompetensi dan teknologi informasi dalam proses pembelajaran menunjukkan peningkatan terhadap kemajuan signifikan dan formasi kompetensi komunikatif. 23

Savignon berpendapat tentang "kompetensi komunikatif" menganjurkan pembelajaran bahasa melalui percakapan, bukan analisis tata bahasa dan terjemahan. Semua bentuk pembelajaran bahasa komunikatif adalah pembelajaran bahasa yang dimulai dengan model komunikatif dan menggunakan bahasa dalam pembelajaran sistem instruksional. Juga mendeskripsikan tentang peran tenaga pengajar dan peserta didik, kegiatan kelas dan teknik yang digunakan. ${ }^{24}$ Manusia sebagai mkhluk sosial cenderung hidup berkelompok. Pada setiap kelompok, manusia menggunakan suatu bahasa tertentu sebagai alat komunikasi, apabila sekelompok manusia telah dapat menggunakan bahasa tertentu, maka komunitas tersebut cenderung melestarikan bahasa tersebut. Pada realitasnya, kondisi ini belum maksimal dapat tercipta pada pembelajaran bahasa asing di Perguruan Tinggi Islam, khusunya IAIN Kendari karena pembelajaran bahasa masih berkutat pada masalah structural atau gramatikal semata.

Pendekatan komunikatif ini bertolak dari teori tata bahasa generatif transformasi yang mengarahkan dosen pada kemampuan mengelola pembelajaran berdasarkan prinsip komunikasi dan membuat peserta didik memiliki keterampilan dan kemampuan berbahasa dalam konteks komunikasi. Pendekatan komunikatif lebih mengutamakan pengetahuan makna dalam berbahasa. Apabila asumsi teoretis tersebut di atas diamati, maka dapat membentuk dua bentuk asumsi. Pertama, asumsi yang menekankan komunikasi sebagai tujuan belajar bahasa atau dengan kata lain belajar bahasa untuk berkomunikasi berdasarkan kaidah bahasa. Kedua, asumsi yang menekankan komunikasi sebagai produk belajar bahasa atau dengan kata lain belajar bahasa dalam situasi sambil berkomunikasi melalui kemampuan menyusun kalimat berdasarkan kaidah bahasa.

Penekanan kegiatan komunikasi dalam pembelajaran bahasa sangat jelas bermuara pada penggunaan bahasa sebagai alat komunikasi. Penggunaan bahasa

\footnotetext{
${ }^{23}$ Madina Murzkhanovna Akeshova et. al, "The Problem of Using Competence-Based Approach and Information Technologies in Formation of Communicative Competence of the Future Specialist" Journal of Creative Education 4, no. 8 (Augustus 2013): 503, diakses 21 Oktober 2017 http://search.proquest.com/docview/1441488176?accountid=136648.

${ }^{24}$ Manoliu and Marius Narcis, "A Communicative Approach to Language- Origin and Development," International Journal of Communication Reasearch 2, no. 2 (April-June 2012): 138, diakses 21 Oktober 2017

http://search.proquest.com/docview/1441488176? accountid=136648.
} 
tersebut selalu tergantung kepada tujuan pengguna bahasa, sehingga pembelajaran bahasa yang dirancang dengan pendekatan komunikatif dapat bertujuan untuk belajar bahasa agar mampu berkomunikasi menggunakan bahasa dalam kebermaknaan. Sedangkan penekanan kegiatan komunikasi yang diumaksudkan sebagai produk pembelajaran bahasa merupakan belajar bahasa tertentu dengan tujuan menciptakan komunikasi dalam konteks susunan kalimat yang terstruktur.

Pembelajaran bahasa asing secara umum telah mengalami perubahan fluktuatif dalam beberapa tahun ini, perubahan tersebut seperti sesuatu yang datang dan pergi sangat santun dan terjadi dalam ruang lingkup budaya yang menjelma sebagai bentuk perubahan dan mempengaruhi tatanan perkembangan pembelajaran bahasa asing di permukaan persada dunia pendidikan, khususnya pendidikan bahasa. Betapapun diketahui bahwa bahasa sebagai kunci dalam proses pertukaran ide dan pikiran antara satu dan yang lainnya, namun tidak jarang terjadi kekeliruan hadirnya tutur dan bahasa itu antara sesama pengguna bahasa. Itulah dinamika penggunaan bahasa di tengah-tengah keragaman pendapat dan keinginan makhluk hidup sebagai pengguna bahasa.

\section{Tantangan dan Peluang Pengembangan Keterampilan Bahasa Arab}

Pembelajaran bahasa Arab pada pesantren Gontor Putri menggunakan beberapa metode dan pendekatan yang diyakini dan dipilih oleh pihak lembaga sebagai acuan penting dalam menjawab tantangan era global, walaupun masih diwarnai corak pembelajaran bahasa berdasarkan metode atau pendekatan struktural. Sebuah hasil penelitian menyebutkan bahwa metode langsung adalah metode yang mendominasi aktivitas pembelajaran bahasa Arab. ${ }^{25}$ Artikel ini mengkaji secara khusus pembelajaran bahasa Arab berdasarkan pendekatan komunikatif, yang juga popular dengan istilah pembelajaran bahasa komunikatif. Berbeda dengan temuan peneliti sebelumnya, Wekke menemukan adopsi model pembelajaran gontor pada madrasah dan pesantren yang tersebar di ketujuh kota pada Provinsi Papua Barat. ${ }^{26}$ Meskipun belum banyak digunakan oleh kalangan tenaga pendidik pondok Gontor Putri 4, model pembelajaran komunikatif telah mngundang pujian dan kritikan. Pihak lembaga pondok mengapresiasi peran para tenaga pendidik yang berinisiatif untuk memaksimalkan persiapan mengajar berbasis kemampuan komunikatif.

Pesantren Gontor Putri 4 telah menjadi pusat pembelajaran ilmu-ilmu keislaman maka kebutuhan terhadap keterampilan berbahasa Arab selalu diminati. Pesantren ini dapat memanfaatkan peluang dengan baik melalui keberadaannya di wilayah Sulawesi di tengah masyarakat yang sedang membutuhkan kehadiran pesantren modern. Meskipun jauh sebelum

25Imam Makruf, “Manajemen Integrasi,” 271.

${ }^{26}$ Wekke dan Andriansyah, "From Gontor to Sorong," 62. 
didirikannya telah ada beberapa pesantren di Provinsi Sulawesi Tenggara ini, tetapi tetap saja para orang tua mencari profil pesantren modern yang ternama untuk putri kesayangan. Peluang ini sekaligus melahirkan tantangan, apakah pesantren Gontor Putri 4 mampu memenuhi harapan orang tua para santri terkait kesuksesan putri mereka dalam penguasaan dan pengembangan keterampilan berbahasa di antara sekian banyak harapan yang digantungkan pada sistem pembelajaran yang berlangsung pada pondok pesantren tersebut. Jawabannya terwujud dengan rangkaian program pondok, yaitu mengidentifikasi keterampilan awal yang dimiliki oleh setiap santriwati untuk dikembangkan pada arah yang lebih maju dan kondusif.

Setiap mata pelajaran pasti memiliki sumber kajian yang berbahasa Arab maka hal ini menjadi tantangan sekaligus peluang bagi pondok pesantren. Kesempatan mengkaji literatur berbahasa Arab membutuhkan komitmen terhadap penguasaan keterampilan bahasa Arab, yaitu kecermatan memanfaatkan keterampilan membaca dalam menelaah dan menganalisis kandungan literatur berbahasa Arab. Kecermatan ini kemudian menciptakan peluang bagi setiap santri untuk bisa bersaing secara murni berlandaskan keluwesan wawasan. Pondok pesantren Gontor Putri mengadakan kegiatan baca kitab tanpa baris atau biasa disebut dengan istilah kitab kuning. Bagi kelas rendah penerapan kajian ini sangat sulit dimaksimalkan, alasan real adalah peserta didik bermodalkan kemampuan dasar yang hampir sama. Hal ini menjadi tantangan berat untuk pondok pesantren Gontor Putri 4 sehingga pihak kampus melakukan seleksi masuk/pendaftran yang didukung dengan intrumen tes, serta pelaksanaan tes yang ketat. Kegiatan ini membuat para santriwati terjebak pada funsi struktural bahasa ajar, meskipun mereka mencoba menelaah fungsi setiap kata dalam rangkaian kalimat tersebut secara mandiri melalui kemampuan membaca dengan keterampilan praktis bukan teoretis.

Tenaga pendidik pesantren merupakan salah satu aspek penting untuk memancing proses komunikasi. Setiap santri diarahkan untuk mereduksi ketergantungan terhadap bahasa ibu secara proporsional. ${ }^{27}$ Sebagai salah satu tantangan dalam pembelajaran bahasa Arab yang dapat menghambat pengembangan keterampilan berkomunikasi adalah ketergantungan terhadap bahasa pertama. Dalam proses belajar mengajar, bahasa pengantar tidak menggunakan bahasa ibu, meskipun masih ada kelas pembelajaran bahasa Arab yang menggunakan bahasa pertama sebagai bahasa pengantar. Para alumni yang telah melewatkan 6 (enam) tahun masa studi pada pondok putri 1, 2 dan 3 mampu menunjukkan keterampilan berbahasa Arab yang baik dan benar, namun tantangannya adalah ilmu dan kecakapan yang dimiliki tidak mudah untuk ditransfer kepada santri. Terlihat beberapa santri memiliki minat dan motivasi

${ }^{27}$ Wekke, “Arabic Language,” 160. 
yang baik, namun terdapat pula santri yang sangat sulit untuk menggenggam motivasi itu shingga memilih untuk berhenti atau mengajukan surat pindah studi. Fakta ini menjadi tantangan berat bagi pesantren untuk mencari solusi agar setiap santri dapat memupuk rasa ketertarikannya.

Salah satu cara pesantren adalah menerapkan model pembelajaran bahasa Arab Komunikatif. Terdapat beberapa hal yang telah disiapkan oleh pihak pesantren terkait upaya tersebut. Penyusunan silabus dan RPP berdasarkan tujuan pembelajaran yang juga telah dirumuskan sesuai dengan jam kerja. Tenaga pendidik mampu menangkap peluang tersebut dengan menyiapkan media pembelajaran yaitu media atau alat belajar untuk membantu proses komunikasi. Strategi lain para tenaga pengajar adalah menciptakan lingkungan berbahasa Arab pada setiap hari tertentu.Mereka dibimbing untuk berkomunikasi sewajarnya dan sangat alami, hal ini dimaksudkan untuk menetralisir perasaan gugup dan kikuk para santri saat memproduksi kata demi kata untuk menyampaiakan ide dan pokok pikiran kepada komunikan lainnya. Prinsip pembelajaran bahasa komunikatif terlihat pada aktivitas pembelajaran bahasa Arab, teramati bahwa santri dapat mendeskripsikan kecenderungannya dengan baik dalam sebuah latihan pada pembelajaran. Secara tertulis, tertuang apa yang diungkapkan oleh santriwati tersebut. Meskipun penyusunan kalimatnya tidak terlalu serupa tetapi tetap menjaga originalitas makna. Kondisi ini adalah representasi pembelajaran bahasa Arab komunikatif.

Peluang untuk menciptakan situasi kondusif berbahasa Arab didukung oleh lingkungan dan sarana prasarana di kampus, namun belum memadai secara kuantitas. Hal ini menjadi tantangan bagi pengelola untuk menganggarkan pengadaan laboratorium bahasa yang lengkap sehingga setiap perta dapat memanfaatkan sesuai dengan jadwal. Pembelajaran bahasa Arab komunikatif dilakukan oleh para tenaga pendidik dengan mengaktifkan stimulus alami pada setiap santriwati, beberapa indikator pembelajaran bahasa komunikatif yang ditunjukkan adalah tidak menekankan pada hafalan dan tidak menegur langsung ungkapan atau tulisan yang keliru dari kemampuan yang diitunjukkan santriwati, tenaga pengajar menyampaikan perbaikan secara persuasif dan bahkan tidak mengungkit ungkit kembali. Hal ini memberi peluang bagi tenaga pendidik untuk membiasakan santriwati menemukan solusi kekeliruannya secara mandiri.

Pesantren Gontor Putri 4 telah menjawab tantangan pengembangan kemampuan bahasa Arab melalui distribusi kosa kata baru setiap hari, terutama bagi santriwati yang memiliki talenta bahasa secara mandiri. Terdapat perbedaan materi bagi kelompok program reguler dengan kelompok belajar intensif, yaitu penambahan satu tahun masa studi dari waktu normal bagi 
pebelajar tingkat menengah atas (SMA).28 Perbedaan alokasi waktu studi tersebut dilandaskan pada rasionalisasi kemampuan dasar bahasa Arab santriwati yang masuk pada jenjang Sekolah Menengah Atas. Tantangan kosa kata baru ada pada pengenalan bunyi kata saat proses penyimakan. Selanjutnya berdampak pada penguasaan keterampilan lainnya, yaitu berbicara, membaca dan menulis. Meskipun demikian, alumni Gontor Putri 4 lebih potensial dan berpeluang menjadi mahasiswa yang mahir dalam bahasa Asing karena kebiasaan berbahasa yang diterapkan di Pesantren Gontor Putri 4. Sebagaimana yang ditemukan Wahyuni pada peneltiannya bahwa alumni madrasah lebih baik kemampuan dasar bahasanya dibandingkan dengan alumni sekolah umum.

\section{E. Kesimpulan}

Corak pembelajaran bahasa Arab di pesantren menjadi penanda dalam kesuburannya karena bahasa Arab menjadi alat komunikasi sekaligus sebagai alat pengkajian ilmu pengetahuan. Salah satu pesantren masyhur di Indonesia, pesantren Modern Darussalam Gontor yang didirikan secara terpisah antara pondok putra dan pondok putri, secara kuantitas telah tersebar di beberapa wilayah Indonesia dan secara kualitas telah mewarnai pergeseran pembelajaran berbasis tradisional menjadi pembelajaran modern. Pesantren Gontor Putri 4 memberi warna pendidikan Islam yang berlangsung di Sulawesi Tenggara. Pengembangan keterampilan bahasa Arab menjadi tujuan pembelajaran setiap pesantren yang meliputi 4 (empat) keterampilan, yaitu: berbicara, membaca, menyimak, dan menulis. Fakta pada pesantren Modern Darussalam Gontor Putri menunjukkan bahwa eksistensinya sebagai lembaga pendidikan Islam telah menjawab peluang dengan melaksanakan sistem pendidikan berbasis manjerial terpusat terkait perekrutan tenaga pengajar dan menerapan kurikulum. Sekaligus menhadapi tantangan yang bervariasi, muali dari pemilihan model dan pendekatan belajar sampai pada tingkat pencapaian pembelajaran bahasa komunikatif dan prakteknya pada kehidupan sehari-hari para santriwati. Indikator utama pembelajaran bahasa komunikatif adalah belajar bahasa dengan merujuk pada tujuan fungsional. Meskipun ditemukan praktek pembelajaran tradisonal pada Pondok Gontor Putri, tetap saja outputnya masih unggul dalam hal kemampuan komunikatif, khususnya pada pembelajaran bahasa Arab.

\section{F. Referensi}

28 Imelda Wahyuni, "Pembelajaran Bahasa Asing pada Perguruan Tinggi Keagamaan Islam Negeri: Kebijakan dan Hasil” dalam Abdul Wahid, dkk., Islam Indonesia Pasca Reformasi (Surabaya: Imtiyaz, 2015), 321. 
Andriansyah, Ismail Suardi Wekke\&. "From Gontor to Sorong: Muslim Minority Practices on Arabic Teaching and Learning." SOSIOHUMANIKA: Jurnal Pendidikan Sains Sosial dan Kemanusiaan, 2016: 49.

Arsyad, Azhar. "Mengefektifkan Pendidikan Bahasa Asing di Universitas." In Membangun Universitas Menuju Peradaban Islam Modern, by Azhar Arsyad, 86. Makassar: Alauddin Press, 2009.

Baharudin, Ismail. "Pesantren dan Bahasa Arab." Jurnal Thariqoh Islamiah, 2014: 17.

Berns, Margie. Context of Competence: Socio and Cultural Considerations in Communicative Language Teaching. New York: Plenum Press, 1990.

Chomsky, Noam. Aspect of Theory of Syntax. Massachusetts: MIT Press, 1965.

Hymes, D. H. "On Communicative Competence." In The Communicative Approach to Language Teaching, by C. Brumfit and K. Johnson (eds.), 142. Oxford: Oxford University Press, 1979.

Hymes, Dell. "Competence and Perfomance in Linguistic Theory." In Language acquisition: Models and methods, by R. Huxley dan E. Ingram (Eds.), 178. London: Academic Press, 1971.

Isbah, M. Falikul. Pesantren dan Aktivitas Sosial-Ekonomi yang Mengakar di Masyarakat. Jakarta: PPIM UIN Jakarta, 2017.

Madina Murzkhanovna Akeshova, et.al. "The Problem of Using CompetenceBased Approach and Information Technologies in Formation of Communicative Competence of the Future Specialist." Journal of Creative Education. Augustus 2013. http://search.proquest.com/docview/1441488176?accountid=136648 (accessed Oktober 21, 2017).

Makruf, Imam. "Manajemen Integrasi Pembelajaran Bahasa Arab di Madrasah Berbasis Pondok Pesantren." Cendekia, 2016: 269.

Mat, A. C. "Situasi Pembelajaran Bahasa Asing di Institut Pengajian Tinggi: Perbandingan antara Bahasa Arab, Bahasa Mandarin dan Bahasa Perancis." Asean Journal of Teaching and Learning in Higher Education (AJTLHE), 2010: 9.

Muhyiddin. Republika.co.id. $\quad$ November $\quad 30, \quad 2017$. https://www.republika.co.id/berita/dunia-islam/islamnusantara/17/11/30/p088lk396-pertumbuhan-pesantren-di-indonesiadinilai- (accessed Februari 17, 2017). 
Imelda Wahyuni

Munby, J. Communicative Syllabus Design. Cambridge: Cambridge University Press, 1978.

Muslim, Muh. Ariadi. Manajemen Pembelajaran Bahasa Arab di Pondok Pesantren Nurul Hakim (Putra) Kediri NTB. Tesis, Yogyakarta: UIN Sunan Kalijaga, 2016.

Narcis, Manoliu and Marius. "A Communicative Approach to Language- Origin and Development." International Journal of Communication Reasearch. April-June 2012. http://search.proquest.com/docview/1441488176?accountid=136648 (accessed Oktober 21, 2017).

Reuter, Thomas A. "The Green Revolution in the Word's Religions: Indonesian Examples in Internasional Comparison." Religions, 2017: 1217-1231.

Richards, J. C. Communicative Language Teaching Today. Cambridge: Cambridge University Press, 2006.

Rodgers, Jack C. Richards dan Theodore S. Approaches and Methods in Language Teaching. New York: Cambridge University Press, 2001.

Savignon, Sandra J. Communicative Competence: Theory and Classroom Practice. Massachusetts: Addison Wesley Publishing Company, 1983.

Solichin, Mohammad Muchlis. "Kemandirian Pesantren di Era Reformasi." Nuansa, 2012: 190.

Wahyuni, Imelda. "Pembelajaran Bahasa Asing pada Perguruan Tinggi Keagamaan Islam Negeri: Kebijakan dan Hasil." In Islam Indonesia Pasca Reformasi, by dkk. Abdul Wahid, 321. Surabaya: Imtiyaz, 2015.

Wei, Hu. "Communicative Language Teaching in the Chinese Environment." USChina Education Review, 2010: 104.

Wekke, Ismail Suardi. "Arabic Language Teaching and Learning in Muslim Minority of West Papua." Jurnal Pendidikan Islam, 2017: 156.

Wekke, Ismail Suardi. "Tradisi Pesantren dalam Konstruksi Kurikulum Bahasa Arab di Lembaga Pendidikan Minoritas Muslim Papua Barat." KARSA, 2014: 22. 